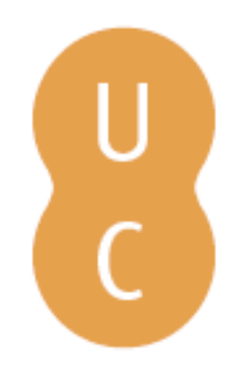

\title{
pompalina
}

\section{Democracia com sofistas}
Autor(es): $\quad$ Ribeiro, Luís Felipe Bellintani
Publicado por: Imprensa da Universidade de Coimbra
URL persistente:
URI:http://hdl.handle.net/10316.2/45156
DOI:
DOI:978-989-26-1679-7 (PDF); DOI:https://doi.org/10.14195/978-989-26- 1679-7_15

Accessed : $\quad$ 26-Apr-2023 10:15:36

A navegação consulta e descarregamento dos títulos inseridos nas Bibliotecas Digitais UC Digitalis, UC Pombalina e UC Impactum, pressupõem a aceitação plena e sem reservas dos Termos e Condições de Uso destas Bibliotecas Digitais, disponíveis em https://digitalis.uc.pt/pt-pt/termos.

Conforme exposto nos referidos Termos e Condições de Uso, o descarregamento de títulos de acesso restrito requer uma licença válida de autorização devendo o utilizador aceder ao(s) documento(s) a partir de um endereço de IP da instituição detentora da supramencionada licença.

Ao utilizador é apenas permitido o descarregamento para uso pessoal, pelo que o emprego do(s) título(s) descarregado(s) para outro fim, designadamente comercial, carece de autorização do respetivo autor ou editor da obra.

Na medida em que todas as obras da UC Digitalis se encontram protegidas pelo Código do Direito de Autor e Direitos Conexos e demais legislação aplicável, toda a cópia, parcial ou total, deste documento, nos casos em que é legalmente admitida, deverá conter ou fazer-se acompanhar por este aviso.

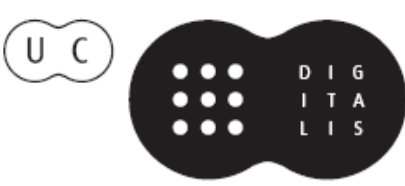



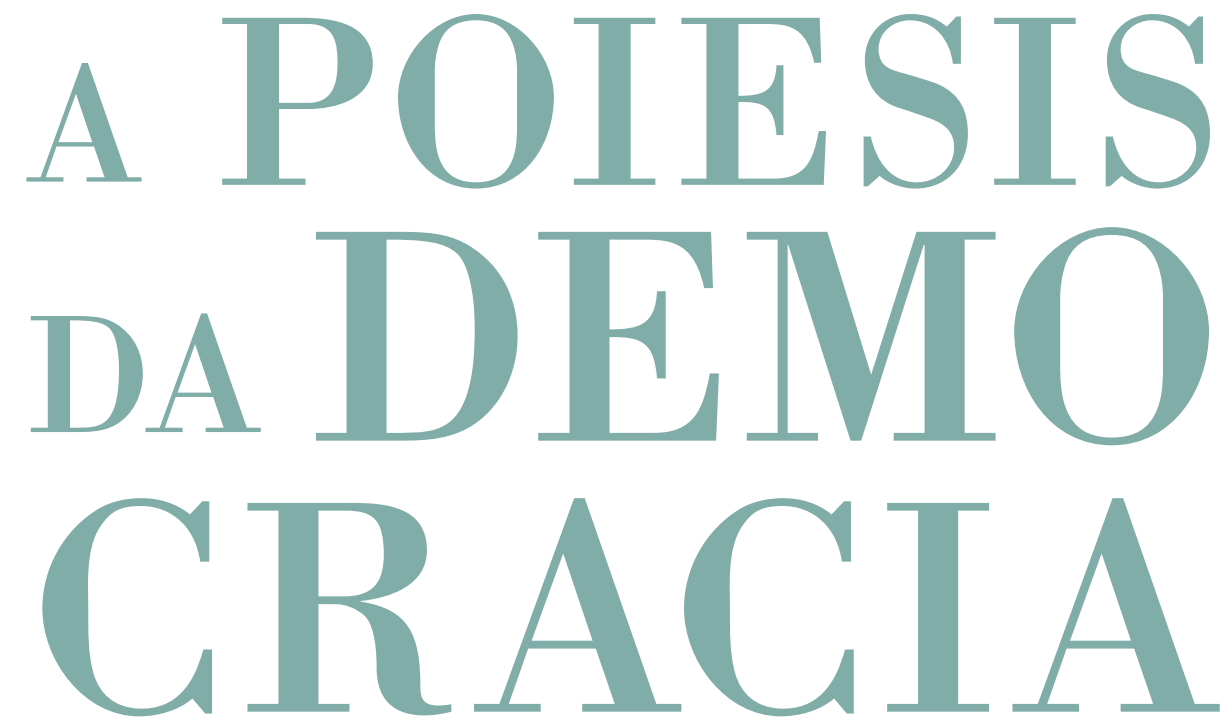

G

Breno Battistin Sebastiani, Delfim Leão,

Lugia Sano, Martinho Soares, Christian Werner

\section{CoimbraCompanions}




\section{Democracia com sofistas}

\section{DEMOCRACY WITH SOPHISTS}

Luís Felipe Bellintani Ribeiro

Universidade Federal Fluminense

ORCID | 0000-0002-5020-4453 


\section{Resumo}

Desde o nascimento da democracia na antiguidade que se reclama em paralelo de sua própria corrupção. Cedo foram nomeados os espantalhos a encarnar o alvo dessa crítica: os sofistas. Bem conhecido é o enredo: a polis democrática engendrou a necessidade de saber falar na assembleia e no tribunal e os sofistas se apresentaram como professores dessa arte, preocupando-se apenas com o elemento de convencimento, e não com a verdade, donde, aliás, a decadência moral. E assim endossamos inadvertidamente a idealização de cunho aristocrático do significante "democracia", com seu tradicional ranço moralista. Mas talvez, ao contrário, seja no legado dos sofistas antigos que haveremos de rastrear sentido para este significante. Afinal foi no âmbito do pensamento sofístico que surgiram os argumentos da diferença entre natureza e convenção, da igualdade natural de gregos e bárbaros, do caráter não-natural da escravidão, da irredutibilidade do domínio político ao da técnica, do vínculo entre pedagogia e política, do caráter problemático da linguagem para além do seu estatuto aparentemente banal de representação do real, do caráter humano e limitado de todo conhecimento, da reserva agnóstica perante a convicção dogmática, da irrupção inevitável do contraditório e da relatividade dos valores religiosos, morais e estéticos.

\section{Palavras-chave}

democracia, sofistas, materialismo, relativismo 


\section{Abstract}

Since the birth of democracy in antiquity, its corruption has been criticized. The target of this criticism was established early on: the sophists. The plot is well-known: the democratic polis engendered the need for the knowledge of speaking in the assembly and in court; and the sophists presented themselves as teachers of this art, focusing only on the element of persuasion and not on truth - indeed, the origin of moral decay. We have thereby carelessly endorsed the idealization of the signifier "democracy" with an aristocratic trait with its traditional moralistic rancidity. Instead, it may be exactly in the legacy of the ancient sophists that we can trace the meaning of this broad term, democracy. In fact, it was in the scope of the sophists' thoughts that the following arguments emerged: the difference between nature and convention, the natural equality of Greeks and barbarians, the unnatural character of slavery, the irreducibility of the political domain to that of technique, the link between pedagogy and politics, the problematic character of language beyond its apparently banal status of the representation of the real, the limited character of human knowledge, agnostic restriction in the face of dogmatic conviction, the inevitable irruption of contradictory speeches and the relativity of religious, moral and aesthetic values.

\section{Keywords}

democracy, sophists, materialism, relativism 
Em torno do significante "democracia", quando se trata de tentar lhe conferir algum significado determinado, circulam de há muito outros tantos significantes de um mesmo campo semântico: "paradoxo" (o ditador que chega ao poder pelo voto), "contradição" (regime do consenso ou do dissenso?), "ambiguidade", "ambivalência" (regime fiador da diferença e fiador da igualdade/ protetor das minorias e do indivíduo ante a opressão do Estado e da maioria, e protetor da decisão majoritária e coletiva ante os egoísmos e as investidas tirânicas e oligárquicas), além de "vagueza" e "indeterminação" (todo mundo é democrata e ninguém confessaria não ser) $)^{1}$.

O que se passa aí é algo familiar à lida filosófica. É que na democracia a política fica entregue a si mesma. Já dizia o Péricles de Tucídides em discurso que não é menos fundação da autoconsciência desse então nascente valor ocidental que homenagem aos concidadãos mortos na guerra (Thuc. 2. 40. 2): "nós mesmos [cidadãos atenienses] decidimos/ somos o critério

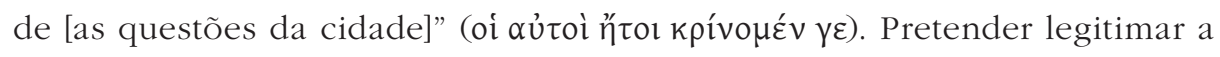
política por alguma realidade pré-existente à política, seja de matiz mais religioso, mais moral ou mais científico, é qualquer coisa no extenso espectro de combinações entre a teocracia e a tecnocracia, talvez possibilidades das quais a democracia jamais consiga se apartar totalmente, já que o demos costuma ir com religião, moral e teorias as mais diversas para a praça pública (inclusive antidemocráticas), mas não é democracia enquanto esse grande metadiscurso da política, que a pensa no ato mesmo de instauração de seu princípio.

Privada de respaldo, digamos, "metafísico", a política na democracia é obrigada a assumir nas próprias costas o insólito que costumava ficar por

1 Cf. Agamben et al. 2009. 
conta de seu critério de outrora. Na metafísica acontece dessas coisas: a primeira causa não tem causa, o primeiro motor não se move, o último fim não é mais por mais nada, o fundamento paira sobre o abismo, sob pena de pagar-se o preço não menos catastrófico da regressão ou extensão ao infinito. Com a locução arche anarchos, tocamos no problema em questão e passamos sem mais do âmbito metafísico (arche: princípio) para o político (arche: governo). Nada mais anárquico que a própria arche. O sufixo -kratia deixa patente o problemático elemento de ruptura, logo violência, encerrado no processo pelo qual uma arche principia seu governo, seu principado.

Na democracia, por um lado, a origem do poder não foi ainda encoberta por um discurso justificativo qualquer, mas está ela mesma em jogo na arena pública - o termo demos enquanto critério nomeia antes esse lugar do que um conteúdo prévio determinado -, numa ágora que também é ambiguamente assembleia e mercado, onde disputam não só discursos racionais, mas todos os tipos de força, verbais e não verbais, até à força bruta. Por outro lado, algum discurso justificativo e suas práticas correlatas têm de prevalecer sobre os demais, e a lei instituída prevalece sobre o ato de instituir. A ambivalência do termo "democracia" não é, portanto, um defeito, mas uma característica constitutiva de sua condição, e não é o caso de pretender dirimi-la, mas de pensá-la radicalmente e de tirar partido dela na prática.

A reclamação de que a tal arena pública degringolou numa azáfama de egoísmos em recíproca exibição e competição, guiados por padrões alienantes de uma publicidade mercadológica, que pode ser tudo menos autonomia, é justa hoje em dia, mas importa reconhecer que ela parece tão antiga quanto a própria democracia. Tratar-se-ia da velha tendência da democracia de se converter em demagogia e, finalmente, como adverte Platão na República (8 e 9), em tirania. Acrescentaríamos outras tendências, aproveitando o mesmo texto platônico, só que agora em sentido contrário ao proposto por Platão. É que ele coloca acima da democracia outros três regimes, os quais colocamos abaixo dela. Falamos da tendência da democracia de se converter também em oligarquia dos ricos ou em regimes militares (timocracia) ou em república dos peritos (aristocracia), ou em uma versão combinada de todas essas fórmulas antidemocráticas. 
O problema dessa reclamação é o lugar que pretende ocupar aquele que a formula. O dos autônomos, olhando de fora os heterônomos, como se autonomia e heteronomia não se digladiassem na alma de todo indivíduo? O da academia olhando para a praça, como se aquela não estivesse nesta? O dos que já sabem o que significa demos, como se não fosse, ao contrário, o saber que dependesse dos significados previamente hauridos por uma língua popular? Não. Sem essa prerrogativa censora autoconcedida, não resta senão disputar o senso comum na fresta de arena pública, se restou alguma.

Desde o nascimento da democracia na antiguidade, aliás, que se reclama em paralelo de sua própria corrupção. Cedo até foram nomeados os espantalhos que haveriam de encarnar o alvo dessa crítica: os sofistas. O enredo é simples: a polis democrática engendrou a necessidade de saber falar de modo convincente na assembleia e no tribunal, os sofistas aproveitaram essa demanda e se apresentaram como professores dessa arte e ganharam muito dinheiro preocupando-se apenas com o aspecto de convencimento do respectivo auditório, prescindindo de qualquer preocupação com a verdade como categoria ontológica e epistemológica, donde, aliás, a decadência moral. Ajuntamos a este enquadramento do passado nosso próprio enfado diante das supostas correlatas tagarelices hodiernas, igualmente, em tese, descompromissadas com a ética e a verdade: judicialização da política, burocratização dos partidos e das instituições, cultura midiática do entretenimento e indústria da propaganda voltada para o consumismo, e endossamos inadvertidamente a idealização de cunho aristocrático do significante "democracia", com seu tradicional ranço moralista. Como se esse ideal subsistisse antes daqueles que foram seus agentes históricos efetivos. Como se fosse possível uma democracia sem sofistas.

E, no entanto, para continuar no campo das inversões dos paradoxos, se olharmos de perto o legado dos sofistas antigos, remanescente aos frangalhos, talvez encontremos aí várias contribuições para uma tentativa de construção de sentido para o termo "democracia" hoje em dia, muito mais, talvez, do que no caudaloso legado dos grandes ícones da tradição greco-romana. 
Em primeiro lugar, cumpre rechaçar sem mais o velho lugar-comum e deixar bem claro: o tema da verdade não está ausente do debate sofístico, nem é ela uma categoria que lhe seja hostil. Ao contrário. O problema aí não é de falta de verdade, mas de excesso, de sobra. Não é à toa que, no intuito de enquadrar o sofista, Platão escreva um diálogo (Sofista), não para provar que o verdadeiro seja possível, pois isso é óbvio, mas para provar que o falso seja possível. Sobra verdade porque todo ser dotado de sensação tem uma experiência efetiva do real e o discurso que daí emerge espontaneamente não tem como não ser correspondente. Ninguém pode não sentir o que sente, de bom ou mau grado, e o que lhe aparece não pode não lhe aparecer. "Todos os pareceres e aparências são verdadeiros"

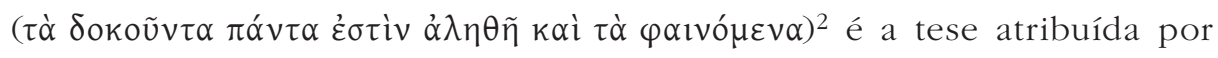
Aristóteles ao sofista Protágoras (Metaph. 4. 5. 1009a8). Hierarquizar os pareceres é uma tarefa problemática, pois no começo todos se nivelam precisamente porque nenhum extrapola o limite de acontecer como singular parecer e aparência. Hierarquizar é certamente também uma tarefa necessária, pois uma constituição é uma hierarquia, um caráter individual é uma hierarquia, e numa hierarquia a sobra de verdade tem de ser sacrificada em prol de um consenso mais ou menos monádico, mas faz toda diferença compreender ou não esse processo criador do valor a partir de uma instância em que os múltiplos pareceres dos indivíduos, das cidades e até das espécies (exemplificadas pelo girino, pelo porco e pelo cinocéfalo no Teeteto) não estejam previamente excluídos.

A noção de "verdade", por seu turno, está atrelada à noção de "natureza", aquilo que é de nascença e pertence à essência. Vale sempre lembrar que os sofistas são pré-socráticos e participam do debate "fisiológico" próprio da época. E há que se compreender como a física da matéria pré-socrática aponta para uma ontologia da igualdade, fato que não deve estar desvinculado do advento da democracia, sempre ligada a algum nível de isotes, seja relativamente à possibilidade de tomar a palavra na praça pública (isegoria), seja relativamente à possibilidade de produção e de submissão à lei-convenção (isonomia), ou outros tipos de igualdade.

2 As traduções do grego sem indicação explícita do tradutor são nossas. 
As noções de "igualdade" e "diferença" são também, como não podia deixar de ser, eivadas de ambiguidade. Ambas podem ser, a depender do aspecto enfatizado, opressivas e libertadoras. A igualdade caminha sobre o fio que separa o nivelamento que torna tudo unidimensional e a fraternidade magnânima. A diferença, sobre o que opõe a exploração de uma elite sobre a massa e a garantia da livre emergência da pluralidade humana.

À noção de "natureza", por sua vez, se opõe precisamente a noção de "convenção", "lei". Eis um fato que permite falar da sofística no singular, por sobre a pluralidade de pensamentos sofísticos diferentes. Cada sofista propõe aproximar ou afastar nomos e physis de um modo bem peculiar, mas é comum a todos a consciência da importância desse binômio conceitual.

Ora, a consciência da diferença entre natureza e lei, pode-se dizer, é a própria ruptura com a clausura cultural ${ }^{3}$, esse paraíso da univocidade, da aderência perfeita de palavras e coisas, da segurança identitária imune à ameaça da alteridade. Não por acaso foi no âmbito do pensamento sofístico que surgiram os argumentos da igualdade natural de gregos e bárbaros ${ }^{4}$, do caráter não-natural da escravidão ${ }^{5}$, da irredutibilidade do domínio político ao modelo da técnica ${ }^{6}$, da irredutibilidade do âmbito público ao âmbito privado (da política à economia) ${ }^{7}$, do vínculo entre pedagogia e virtude política $^{8}$, do caráter problemático da linguagem para além do seu estatuto

3 Cf. Castoriadis 1986: 261: "Jusqu'à la Grèce, et en dehors de la tradition gréco-occidentale, les sociétés sont instituées sur le principe d'une stricte clôture : notre vision du monde est la seule qui ait un sens et qui soit vraie - les 'autres' sont bizarres, inférieurs, pervers, mauvais, déloyaux, etc."

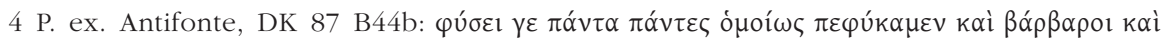

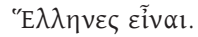

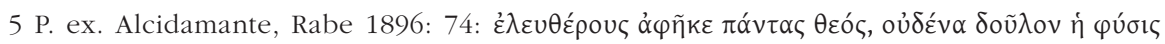
$\pi \varepsilon \pi \operatorname{oí}_{\kappa \varepsilon v .}$

6 P. ex. Protágoras (Pl., Prt. 316b8-323c2): ao longo de todo o trecho, que culmina no mito antropogônico, que fala da diferença na distribuição do pudor e da justiça relativamente à distribuição das technai específicas; Platão, sexta definição de sofista (Sph. 229d1-2): demiourgikas didaskalias versus (diferença) paideian. Todas as citações e traduções de Platão neste texto seguem Burnet (1907).

7 P. ex. Antifonte, DK 87 44a: meta martyron versus (oposição) monoumenos martyron; Protágoras, idem nota 6: peri ton oikeion versus (complementação) peri ton tes poleos.

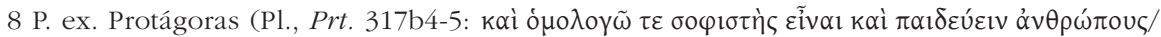

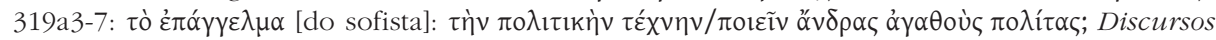

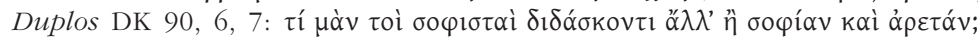


aparentemente banal de representação do real ${ }^{9}$, do caráter humano e limitado de todo pretenso conhecimento objetivo ${ }^{10}$, da reserva agnóstica perante a convicção dogmática ${ }^{11}$, da irrupção inevitável de dois discursos contrários em torno de toda causa ${ }^{12}$ e da relatividade dos valores religiosos, morais e estéticos ${ }^{13}$.

Uma ambiência assim secularizada não é algo a ser simplesmente enaltecido (libertação da clausura) ou execrado (expulsão do paraíso), nem algo que os nela concernidos possam escolher ou rejeitar sem mais. Talvez esse fatídico que acometeu a Grécia, certamente por razões históricas e não metafísicas, seja o fatídico de toda época ocidental que pressente nos gregos o começo de si mesma. Cabe, no entanto, aceitá-lo com amor fati. Se nestas paragens não é mais possível contar com o sujeito autônomo como substitutivo dos antigos critérios teocráticos, também não é possível simplesmente aceitar que se reestabeleça um regime monocrático qualquer, a ser fundado num critério fatalmente relativo, mas que se autoconceda ares de absoluto. Compreende-se o fastio diante do termo "democracia", mas talvez seja o caso de continuar a falar dele, com falatório e tudo, e em favor não apenas de uma liberdade negativa (não ser obrigado a), mas também de uma filosofia substantiva da multiplicidade e da igualdade.

A ideia de que a democracia se funda numa filosofia substantiva é mais uma maneira de formular seu paradoxo constitutivo. Não deveria ser ela uma forma vazia a garantir a livre circulação dos diversos conteúdos? Sim, por um lado, mas sua forma nunca é totalmente vazia. A garantia do dissenso depende de um consenso mínimo de fundo. Para o adepto de uma determinada religião sua verdade não é apenas uma metáfora permutável pelas metáforas de outras religiões, mas enquanto cidadão de uma polis

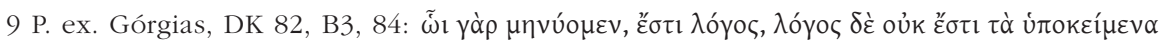

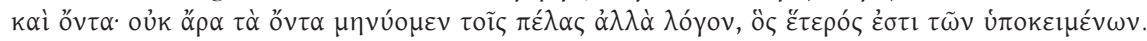

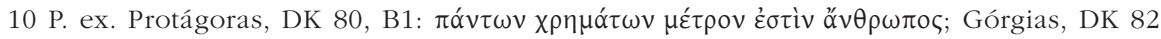

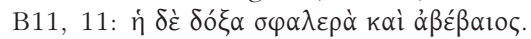

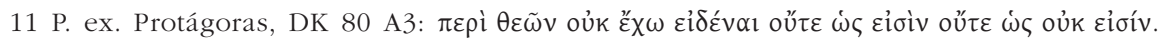

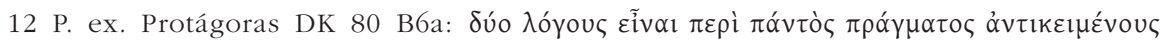

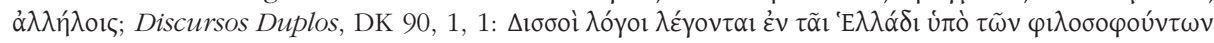

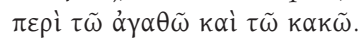

13 P. ex. Discursos Duplos, DK 90, todo o capítulo 2, onde se lê no §18: oủ үà

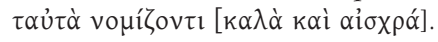


democrática ele terá de aceitar minimamente (como ato resignado que seja), no contexto de um ecumenismo ou de simples tolerância, a tese do caráter relativo da verdade.

A formulação do agnosticismo, por exemplo, como a de Protágoras, funcionaria como uma espécie de metadiscurso, igualmente distante da pretensão dogmática das religiões e da do ateísmo, a assinalar um patamar de igualdade no campo gnosiológico, mesmo para quem depois quiser hierarquizar desigualdades no campo teológico. Aliás, a própria palavra "hierarquia", ao remeter à ideia de um poder fundado num sagrado (bieros), logo numa desigualdade relativamente a um ordinário profano, dependeria de certo viés teológico. A formulação de Protágoras é o avesso de qualquer impiedade, pois a razão de não se saber sobre a existência ou a forma de deus ou dos deuses é exatamente a obscuridade da questão em comparação com a brevidade da vida humana. Nenhuma bybris aí. Antes o ateu e o crente é que deveriam se ruborizar da arrogância de suas pretensões sobrehumanas de saber. Uma tal humildade terá de ter o cidadão que quiser pactuar uma vida coletiva possível, num contexto pacífico em que cada um professe em privado a religião ou a não-religião que lhe aprouver.

É também nos quadros de uma filosofia da finitude que deve ser pensada a tese protagórica do homem como medida de todas as coisas. Que o real apareça para o homem somente no limite da percepção humana, isso não é uma prerrogativa que o homem tenha dado a si mesmo, ao contrário, é um limite que lhe é imposto pela natureza, só lhe restando a ele resignar-se. O homem não escolhe qual fenômeno há de aparecer, mas o fenômeno, soberano, há de aparecer ao homem no limite da medida humana de todo modo. A sabedoria de Protágoras, ao invés de sugerir um antropocentrismo, funciona como precaução diante da tendência mui humana de colocar-se no centro, mas falar como se fosse da essência das coisas, naturalizando sua interpretação.

Se o homem é o indivíduo humano, ela (a sabedoria de Protágoras) significa positivamente o direito de cada um de viver conforme sua aparência, e negativamente a interdição de uma aparência individual pretender ser mais verdadeira ou real que outras. Umas podem ser melhores, outras piores, mas já numa hierarquia de bem e mal fixada pelo nomos e que 
pode mudar a todo instante. Se o homem é a cidade humana, ela (a sabedoria de Protágoras) sugere positivamente o multiculturalismo e negativamente a interdição ao etnocentrismo. Se o homem é a espécie humana, ela implica positivamente - e paradoxalmente, como o Sócrates platônico bem percebe no decorrer do debate travado no Teeteto - que as outras espécies, como o porco e o cinocéfalo, possam ser outras tantas medidas de percepção do ser não menos verdadeiras, mas negativamente que a espécie humana esteja fadada ao limite de sua medida humana, limite esse, como se disse, imposto pela natureza e à revelia do homem.

Mas a "natureza" de que trata o movimento sofístico é também aquela de que tratam os filósofos desde os primórdios, não apenas "natureza" no sentido de "essência" restrita ao debate acerca da natureza humana, mas também no sentido daquilo que hoje colocaríamos no campo das ciências naturais e da cosmologia. Também nesse sentido os sofistas são pré-socráticos. E, como diz Aristóteles (Metaph. 1. 3. 983b6-8)14, "a maior parte dos primeiros filósofos considerou como princípios de todas as coisas apenas os que são

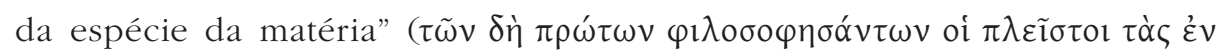

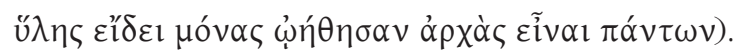

E ele explica o que seria um princípio da espécie da matéria (Metaph. 1. 3. 983b8-10): "aquilo desde que todos os entes são e desde que primeiro vêm a ser, e em que por fim se degeneram; a essência, por um lado, permanecendo no fundo e, por outro lado, se transformando quanto às

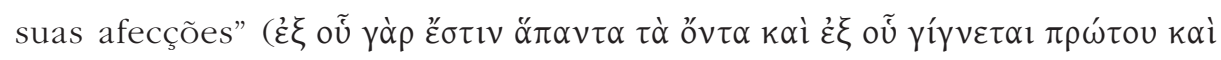

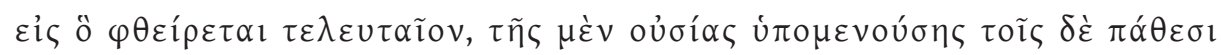

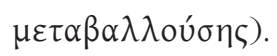

Ato contínuo, o Estagirita dá o exemplo de Tales, para quem o elemento água cumpre o papel deste princípio ${ }^{15}$. Mas ele pode ser também o ilimitado ${ }^{16}$, o ar, o fogo, os quatro elementos em pé de igualdade, a mistura de tudo antes da atuação do nous, o turbilhão de átomos antes de formar mundo.

14 As citações de Aristóteles, nesta e demais passagens, são do texto de Jaeger 1957.

15 Cf. Homero (Il. 14. 201): "Oceano, gênese dos deuses, e a mãe Tétis"

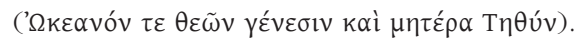

16 Cf. Hesíodo (Th. 116; texto em Solmsen 1970): "Primeiro, certamente, nasceu Caos"

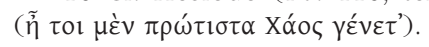


De todas as várias questões implicadas nesse pensamento, trata-se aqui de destacar apenas um aspecto: a anulação das diferenças que separam e hierarquizam os entes, em favor de uma origem e um destino comuns. Os entes são na verdade afecções da mesma essência, à medida que essa se transforma, e, enquanto eles nascem e morrem em perpétuo revezamento, ela permanece no fundo. Por esse pensamento, o princípio de identidade que vigora no domínio pós principium individuationis, pelo qual cada indivíduo é idêntico a si mesmo e distinto dos demais, não vigora ainda, pelo que não se pode dizer que cada coisa seja idêntica a si, ou, melhor, pelo que se tenha de dizer que cada coisa seja na verdade idêntica às demais. Tudo é um. Transposto esse pensamento para o domínio da política, compreende-se a tendência da direita, verdadeiro foco na dimensão diferenciada e hierarquizada da realidade em primeiro plano, em detrimento do pano de fundo, de imputar mérito e culpa aos indivíduos por suas respectivas condições efetivas, em oposição à tendência da esquerda de, ao inverter o efeito bokeh, abrandar as culpas e os méritos individuais na totalidade do sistema. Certamente, nenhuma dessas posições é mais ou menos real que a outra, uma vez que se baseiam ambas em limites inelutáveis da condição humana: ser sempre individual e intransferível, fundamento do egoísmo, e ser sempre aberta para tudo que é seu outro, a ponto de formar sua identidade por mimetismo dessa alteridade, fundamento do altruísmo. Tampouco haveria realidade, houvesse apenas matéria ou apenas forma, mas as consequências, a depender do polo que se enfatize, são muito diferentes. E agora trata-se de enfatizar o polo da matéria.

Ora, o maior consolo para aquele que sabe que vai morrer deveria ser esse sentimento fraternal relativamente a todas as coisas do universo, que compartilham a permanência da essência material comum no falecimento da própria afecção. As fezes dos vermes que decomporão nossos cadáveres tratarão de repor nossa matéria no circuito da natureza, até que volte a ser poeira estrelar. Como não adianta tentar postergar indefinidamente a existência, o melhor seria cuidar da qualidade desse lote finito inelutável, que já começou a transcorrer, aliás, desde o nascimento. Um tal pensamento desaconselha a vaidade e a inveja - que dependem da ênfase na afecção perecível em detrimento da essência que permanece - como colaboradoras 
nesse cuidado. Compreende-se, em sentido inverso, que a vaidade e a inveja se convertam em quase virtudes para a cosmovisão de direita, apologeta da competição e da meritocracia.

Quando o supramencionado Tales fala - e mesmo que não seja verdade o relato de Diógenes Laércio (1. 1. 35) ${ }^{17}$, ele vale como símbolo do dito "materialismo" dos primeiros filósofos - que "a vida não difere da morte", o que exatamente ele quer dizer? Talvez ele queira dizer o seguinte: esteja ou não a água conformada nos limites deste ou daquele ser vivo, haverá de todo modo água; vivo ou morto o ser vivo conformado, sempre viva estará em todo caso a água disforme. A água: incolor e por isso mesmo capaz de assumir todas as cores; inodora e prenhe de todos os cheiros; insípida e passível de receber todos os gostos; liquidez esparramada que se amolda ao limite de todo receptáculo. O ser fundamental é mais não-ser que ser. Niilismo? O niilismo é só um dos lados sobre os quais se arrisca a corda bamba da filosofia trágica, já que o não-ser é, por outro lado, matéria e potência de todas as coisas. O anedotário de Tales está cheio de sabedoria de Sileno própria de um materialismo radical (Diógenes Laércio

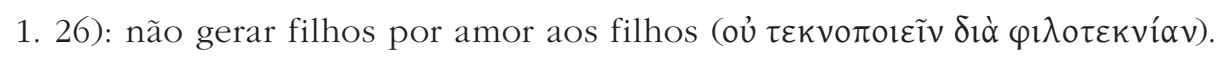
Mas a água é também símbolo mor da vida: toda semente é úmida e toda umidade é seminal.

E, como diz outro pré-socrático, não obstante todo ente tenha de pagar castigo e penitência pela injustiça que é seu próprio vir-a-ser, e paga-o definhando e deixando de ser, tanto esse gerar-se quanto esse corromper-se se dão por necessidade, e não poderiam ser suprimidos por um desejo puramente pessimista ou puramente otimista. O otimismo no caso equivaleria à pretensão de salvaguarda da forma limitada; e o pessimismo, à desistência de sua geração, fadada que está à destruição. Ambos, por sua vez, otimismo e pessimismo, se ligam a uma filosofia da forma limitada, mas se trata agora de uma filosofia da matéria ilimitada, portanto, de uma filosofia trágica, exemplarmente representada tanto pelo apeiron de Anaximandro, quanto

17 Texto em Goold 1991, aqui e abaixo. 
pelo arrythmiston do sofista Antifonte ${ }^{18}$. Também não deve ser mera coincidência que democracia e tragédia tenham brotado do mesmo solo espiritual. Pagar justiça pela corrupção e pela morte é o que torna todo ente igual. É uma questão de perspectiva. Os eventuais desnivelamentos entre os entes, por maiores que pareçam visto de perto, nivelam-se vistos de longe, sobretudo se a distância é a que distingue o ente temporal da "ordem do tempo" (he tou chronou taxin) ela mesma. As recentes teorias cosmológicas sobre o tamanho e a antiguidade do universo só incrementam a imaginação de há muito existente sobre o assunto.

Curiosamente, diversas teorias emanadas de diversos domínios científicos têm vindo ao encontro dos princípios filosóficos pré-socráticos. A antropologia e a história ensinam que o homem não existe ab aeterno, nem desde um único ato criador, mas vem a ser desde o ser vivo não-humano numa continuidade que confunde, numa zona obscura, suas fronteiras com as da biologia. E o mesmo se passa com o ser vivo relativamente ao ente puramente geológico, e com este relativamente ao ente astronômico e cosmológico. Até as estrelas geram-se e corrompem-se. Corrompem-se dissolvendo-se na poeira de seus constituintes últimos, da qual virão as novas estrelas, quando outros pontos de gravidade produzirem o movimento contrário de concentração.

Listemos alguns itens que constituem esse pensamento materialista: proveniência comum, vir a ser e deixar de ser de todas as formas, permanência somente da matéria, que é comum em tudo, total imanência das potências produtivas e destrutivas da matéria, desenvolvimento cuja eventual postulação de teleologia não é incongruente com a noção de acaso. Mera coincidência relativamente a noções caras à democracia, como igualdade, laicidade, alternância no poder, sorteio para preenchimento de cargos públicos?

18 DK 87 B15: A natureza (physis), para alguns, e a essência (ousia) dos entes por natureza, parece ser o primeiro subjacente em cada um, por si mesmo destituído de forma (arrythmiston), como, por exemplo, a natureza da cama seria a madeira e a da estátua, o bronze. Como prova, diz Antifonte que se alguém enterrasse uma cama e a putrefação tivesse poder de fazer levantar um rebento, esse não viria a ser cama, mas madeira, existindo a primeira por acidente (symbebekos), por disposição segundo a lei (nomon) e por arte (technen), enquanto a segunda seria a essência (ousia), a qual permanece e padece continuamente essas coisas. 
Todavia, não se trata obviamente de pensar que o discurso científico deva ter hegemonia a priori na arena da política. Se quiser ter hegemonia, isso precisará ser conquistado pelo convencimento. A história ocidental já ensinou que não é o caso de uma razão iluminista poder jactar-se de seu esclarecimento. Até porque, nos mesmos fatos acima descritos, muitos verão justificativa para a teleologia antropomórfica e para a transcendência. O consenso, no entanto, que deve nortear os partícipes de uma arena democrática é o da presunção de certo grau de igualdade inicial envolvendo todos os discursos, científicos, religiosos ou de outro tipo, no tocante a servirem de base para pautar a vida coletiva. As hierarquias serão estabelecidas depois, nos debates, e é para isso que se precisa de sofistas em uma democracia. Sacerdotes e cientistas só enquanto retores podem pretender comandar a política. Enquanto tais devem ser comandados pela isegoria e pela clepsidra. As competências técnico-epistêmicas, desigualmente distribuídas, enredam os homens em mil e uma assimetrias de poder, mas o pudor e a justiça, fundamento da virtude política, foram distribuídos a todos, conforme ensina o sofista Protágoras em célebre mito, legado por um de seus vários admiradores (Platão, Prt. 320c8-322d5). E foram distribuídos a todos não necessariamente em cotas iguais, mas para a administração desse novo problema existe a educação, conforme ensina de novo o mesmo Protágoras, já que a educação opera sobre algo que de certo modo é comum a todos, caso contrário sequer poderia aspirar ao êxito, mas também que não lhes é dado acabado desde o início, pois então seria anódina.

E fundar a criação do valor na operação discursiva e persuasiva (e não em uma justiça natural, em leis não escritas ou numa ideia de bem) não tem nada de amoral. Trata-se de respeitar a indiferença que caracteriza a natureza e legar ao nomos a tarefa de estabelecimento das clivagens que hão de fazer a diferença. Pois, se, como diz Demócrito, a cor, o amargo e o doce existem por convenção, já que em verdade existem apenas os átomos e o vazio ${ }^{19}$, que não são nem coloridos, nem amargos, nem doces, e se, no entanto, os homens vivem num mundo de cores e sabores, no qual nenhum átomo nem o vazio chegaram jamais a serem percebidos por nenhuma

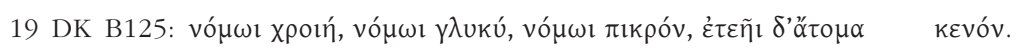


sensação, então a vida dos homens tem muito mais a ver com a convenção do que com a verdade, muito mais a ver com o estabelecimento da lei do que com a descoberta de uma essência prévia, que só poderia levar à constatação do acaso e da indiferença: atirar no peito de alguém ou entregar flores em suas mãos seriam casos idênticos de átomos se movimentando no vazio, conforme a aleatoriedade de uma causalidade mecânica.

Talvez à luz dessa filosofia pré-socrática, cuja melhor expressão é o fragmento supramencionado do sofista Antifonte que fala do arrythmiston, ou dessa filosofia sofística, exemplarmente ilustrada pelo fragmento do pré-socrático Demócrito acima referido, comece a parecer menos estranha a dupla afirmação atribuída por Plutarco ao sofista Górgias de que "o que ilude é mais justo do que o que não ilude, e o que se deixa iludir é mais sábio do que aquele que não se deixa". ${ }^{20}$ Afinal, se o orador Nestor não tivesse persuadido os gregos de que era mais doce permanecer no campo de batalha do que retornar para casa nas côncavas naus ${ }^{21}$, não faltaria verdade e realidade ao mundo, mas faltaria a Homero a matéria-prima de seu canto e faltaria ao mundo o próprio Homero (e à Grécia quem a educasse). E, neste caso, contrariamente ao que diz o adágio, melhor seria deixar de lado a amiga verdade e seguir empós do amigo Homero. Eis um pensamento que lembra não apenas Nietzsche e suas "verdades nocivas" ${ }^{22}$, mas também Platão, e suas "mentiras úteis" 23 , filósofos mais próximos do ideário democrático do que se poderia imaginar, apesar da fama de antidemocráticos, e precisamente por pensarem a política no seu ato de criação e como disputa no campo da linguagem. Lembremos que é obra de Platão também tudo que vem pela boca de Trasímaco (livro I da República), toda aquela história de que não dá para falar de verdade e justiça senão a partir dos nomoi respectivos das diferentes cidades.

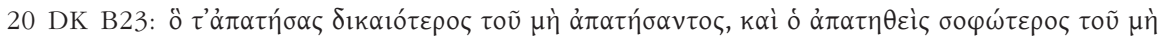

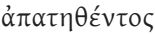

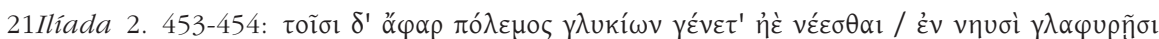

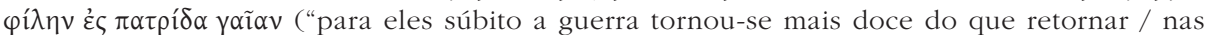
côncavas naus para a amada terra pátria"); texto em Monro \& Allen 1902.

22 Cf. Nietzsche (1873): "schädlichen und zerstörenden Wahrheiten".

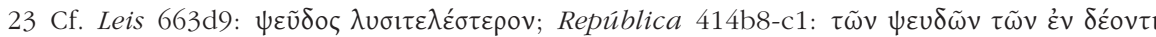

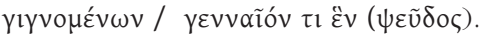


Na sequência (369c9 em diante) Platão põe Sócrates a criar (poiein) uma cidade com a linguagem (toi logoi) como réplica a Trasímaco. O âmbito dessa poiesis é a pequena assembleia de amigos - até Trasímaco entra na bomologia lá para as tantas ${ }^{24}$ - formada em casa de Céfalo. Sócrates não se apresenta como superior a nenhum dos outros nomótetas e fundadores de cidades (oikisteis poleos) e tenta persuadi-los pelo fio de uma racionalidade universal. Só a bomologia a cada passo garante a bomonoia geral. A obra, ao final, resulta mais em um "modelo no céu" (દ่v oủ $\alpha \nu \tilde{\omega} \pi \alpha \rho \alpha ́ \delta \varepsilon \imath \gamma \mu \alpha, 592 b 2)$, a servir de norte para os participantes daquele fórum isonômico, quando estes estivessem com os problemas políticos concretos, do que em algo a ser aplicado tal e qual. O problema não está no conteúdo do modelo, fundado num princípio que é o mais persuasivo de todos e o que mais conquista adesão, o princípio do bem. Quem se oporia à ideia de que cada um realiza a obra para a qual nasceu, sem nenhum constrangimento e no limite de sua perfeição, e que os mais aptos para cuidar do bem comum assim o façam, sem constranger à participação no governo aqueles que não o desejam? O problema é quem vai ficar encarregado na cidade concreta de avaliar a correspondência natureza-obra de cada indivíduo, e escolher aqueles a receber educação de guardião. O problema não é nem tanto que aquele que vê o bem deva governar, mas quem é que diz quem é o que vê o bem. Ou seja, o problema volta para o patamar em que estão Sócrates e seus interlocutores, para o da assembleia fundacional, para o da poiesis de uma cidade desde o princípio pela linguagem. São eles que põem cada cidadão em seu lugar no princípio.

Mesmo que um homem argua haver descoberto um sistema fundado não em suas idiossincrasias, mas numa natureza existente em si mesma, isso só virá a claro para os outros homens como arguição de um indivíduo. Esse é o sentido da tese da primazia da doxa, que circulou com força pelo pensamento grego, e que favorece a identificação da ágora política com a instância última de decisão do sentido a prevalecer.

Parmênides já dizia (DK 28, B1, 31-32):

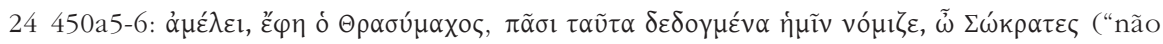
te preocupa, Sócrates - disse Trasímaco - considera estas opiniões como de todos nós"). 
Mas também isso aprenderás: como as aparências têm de aparentemente ser, passando todas através de tudo. ${ }^{25}$

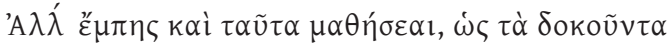

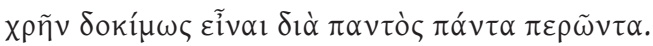

E Górgias (Elogio de Helena, DK 82, B11, 11):

Com efeito, se todos tivéssemos acerca de tudo memória dos eventos passados, inteligência dos presentes, e presciência dos futuros, o discurso, embora sendo de modo semelhante, não iludiria da mesma maneira. Mas não é de fácil acesso, nem ter memória do passado, nem examinar com rigor o presente, nem predizer o futuro. De modo que, na maior parte dos casos, a maioria fornece à alma a opinião como conselheira. E a opinião, sendo movediça e incerta, lança os que se utilizam dela em êxitos movediços e incertos.

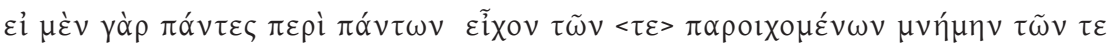

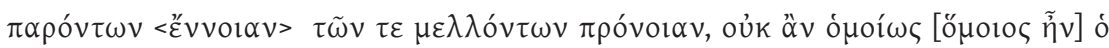

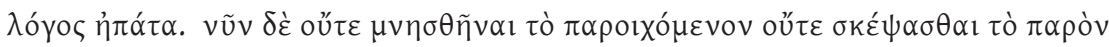

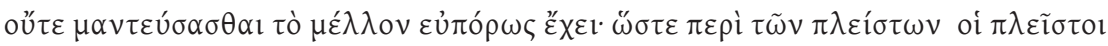

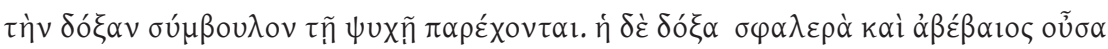

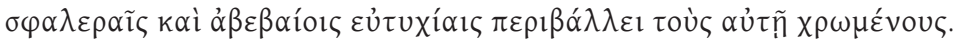

E Isócrates (Antídosis, 271): ${ }^{26}$

Visto que não está na natureza dos homens adquirir uma ciência tal que seus possuidores soubessem o que se deve fazer ou o que se deve dizer, considero, portanto, sábios os capazes de alcançar com suas opiniões o melhor na maior parte dos casos, e considero filósofos aqueles que se

25 Tradução em Santos 2002.

26 Texto em Mathieu 1942. 
exercitam com afinco nessas coisas e que, por isso, mais rapidamente adquirem tal sabedoria prática.

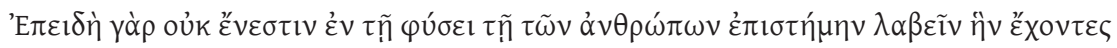

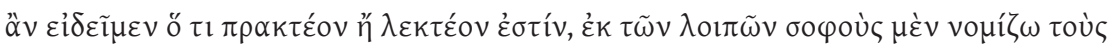

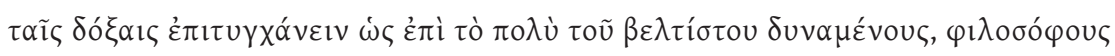

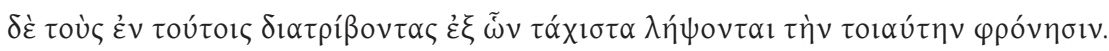

Com efeito, a ideia de que a doxa é soberana associa-se sem mais à tradição sofística, a despeito deste ou daquele testemunho particular. Trata-se sem dúvida de mais um efeito do construto platônico, que não é nem um puro espelhamento fiel dos fatos, nem uma invenção meramente arbitrária. Bem conhecida a oposição platônica filodoxia versus filosofia, opinião versus ciência, aparência versus ser, por cuja perspectiva normalmente se lê o binômio parmenídico doxa/aletheia. Gostaríamos neste quesito de assumir explicitamente a posição isocrática, já insinuada desde o início do texto, em prol de uma filosofia da doxa. Segundo a posição isocrática, filosofia não seria o rebaixamento ontológico da doxa em favor do ser, da verdade ou da ciência, mas seria precisamente a tomada de consciência de que a doxa atravessa tudo - como diz Parmênides em versos tão negligenciados pela interpretação mais tradicional da filosofia do eleata - contrariamente à inconsciência dos desatentos, que costumam tomar por verdade somente o que se lhes aparece, e a rejeitar as aparências dos outros que contradigam as suas.

Vale repetir e enfatizar a razão deste posicionamento favorável à primazia da doxa. Indo direto ao mais extremo dos argumentos, numa versão variante daquele notabilizado por Descartes sob a imagem do "gênio maligno", também em momento de extrema argumentação: mesmo que Deus em pessoa nos dissesse de viva voz qual é a verdade última do universo, isso ainda seria uma cena que aparece, tão fenomênica quanto todas as outras, a despeito das eventuais mil gradações que as distingam quanto à verossimilhança; e ainda pairaria a dúvida de se ali o senhor do universo de fato se desnudava ou se não passava de alguma mise-en-scène sua com ainda algum bastidor atrás. Qual deus atestaria tratar-se aquele de genuíno 
deus? E qual outro relativamente a este outro? E assim por diante. Tampouco poderia alguém afirmar que as aparentes verdades que nos aparecem tais não sejam verdadeiras, isto é, espelhamento fiel dos fatos, mas nossa condição é como a dos homens de Xenófanes que procuram ouro no quarto escuro $^{27}$ : mesmo que peguemos o ouro nas mãos não temos critério para atestá-lo, e então acabamos por soltá-lo...

Vem daí a tese protagórica segundo a qual sobre cada coisa (pragma: assunto, causa, negócio) existem sempre dois discursos contrários um ao outro. A assunção da contradição, que num plano puramente lógico parece consistir no crime capital de lesa-razão, no plano político consiste no apanágio mor da democracia. Situação sem oposição é ditadura, tanto quanto no tribunal seria, se o acusado não tivesse direito ao contraditório. E se há recintos emblemáticos da Grécia clássica, nos quais se espera grande afluxo de sofistas, para bem ou para mal, se é que faz sentido essa distinção, estes são precisamente a assembleia e o tribunal. Acrescente-se nesta lista o teatro, em que se encenam as tragédias, nas quais tampouco é simples a distinção entre bem e mal. Políticos, advogados, professores e atores, artífices de duas caras, encenadores por excelência, mestres da antilogia, continuarão a ser, enquanto o Ocidente respirar, os avatares dos velhos sofistas, por mais que a bonomia do ocidental sério torça-lhes o nariz em favor dos portadores de discursos monológicos, os quais para a massa vestem batina, e para a elite, jaleco, embora também às vezes ao contrário.

O enunciado mais lapidar do princípio que interdita a contradição simples, que é o de Aristóteles no livro gama da Metafísica (1005b19-22), isto é, que interdita dizer que "o mesmo subsiste e não subsiste", depende de três relações: de tempo (hama: "ao mesmo tempo"), de "lugar" ou instância (autoi: "no mesmo") e de aspecto (kata to auto: "segundo o mesmo"). Aristóteles ainda acrescenta um parêntese, numa cláusula preventiva contra qualquer outra nuance pela qual um sofista pudesse criar uma homonímia:

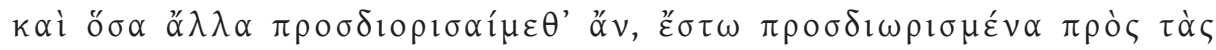

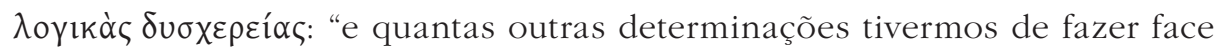
às dificuldades lógicas, façamo-las".

27 Cf. Sexto Empírico, Contra os Lógicos 1, 52; texto em Goold 1983. 
Acontece que em política essas relações supramencionadas (tempo, instância e aspecto) são fundamentais e estão de saída eivadas de mobilidade e multiplicidade - mormente não é ao mesmo tempo, nem sobre o mesmo, nem segundo o mesmo aspecto que os enunciados são ditos - e como nem todas as nuances implicadas serão explicitadas, os enunciados simples contraditórios hão de aparecer, fatalmente.

A verdade de um enunciado monádico dependeria de uma oportunidade toda ímpar, de hipertrofia da identidade, em que um mesmo subsistisse num mesmo ao mesmo tempo segundo o mesmo aspecto, daí que a noção de kairos tenha se tornado chave para o movimento sofístico durante o período marcado por assembleias, tribunais e exibições. O bom orador é aquele que apresenta as teses acerca das quais seu auditório não exigirá a explicitação de todas as nuances. Algum grau de equivocidade sempre passará batido, em favor da concórdia em torno de causas maiores.

Eis aqui o sentido quase mágico da bomonoia (consenso, concórdia, senso comum) poetizada pelos discursos: fundar unidade e identidade no âmbito da cidade preservando a multiplicidade e a diferença dos indivíduos no âmbito privado, gerar concórdia e consenso em torno da necessidade geral de obedecer às leis, lá onde a idiotia estética e noética deveria gerar individualismo antissocial.

Vale a esse propósito citar a passagem de Xenofonte (Mem. 1. 4. 16) sobre a homonoia, que os editores do sofista Antifonte justapõem aos fragmentos remanescentes de uma obra sua de mesmo nome (DK 87, B44a 8-19; grifo nosso):

Mas lhe parece que o consenso é o maior bem para as cidades e que nelas, muito frequentemente, as assembleias dos anciãos e os melhores varões exortam os cidadãos a compartilhar do mesmo senso; e por toda parte na Hélade vigora uma lei que impele os cidadãos a jurar em sermão compartilhar do mesmo senso, e por toda parte <efetivamente> proferem um tal juramento; eu, porém, julgo que isso acontece não como se os cidadãos decidissem pelos mesmos coros, nem como se louvassem as mesmas flautas, nem como se fossem tomados pelos mesmos poetas, não a fim de se comprazerem, mas a fim de serem persuadidos a obedecer às leis, pois as cidades dos cidadãos 
que nelas perseveram tornam-se as mais fortes e as mais felizes; sem consenso, nem a cidade se cidadaniza bem, nem a casa se dá belamente naquilo que é próprio da casa.

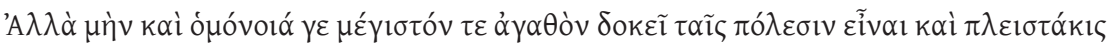

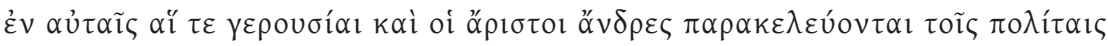

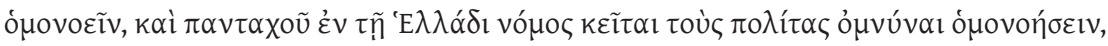

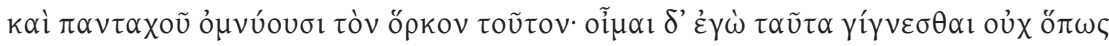

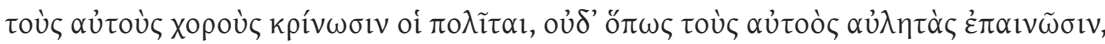

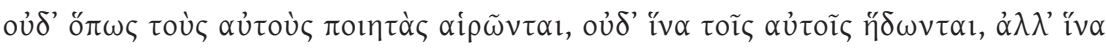

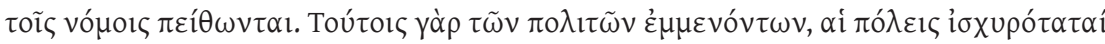

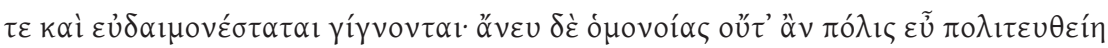

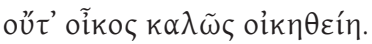

Ou ainda o Anônimo de Jâmblico (DK 89, 6, 1), texto do século quinto certamente ligado à tradição sofística - a euglossia entra em pé de igualdade na lista de virtudes: "sabedoria ou coragem ou eloquência ou virtude" (zُóv

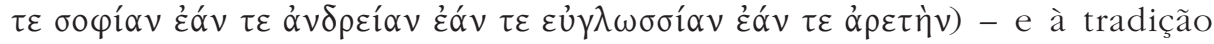
democrática - o plethos (a massa, o grande número, o povo) é mencionado explicitamente no final do texto -, quando argui pela legalidade e contra a ambição (pleonexia) individual, pela força do grande número unificada em consenso (democrático), contra o argumento da democracia como reação dos mais fracos (Gláucon do livro II da República) perante a supostamente legítima imposição dos mais fortes por natureza (Cálicles, Trasímaco?):

Ademais, com efeito, é preciso não lançar-se à ambição, nem achar que é virtude o poder fundado na ambição, ou que é covardia obedecer ao poder das leis, pois este pensamento é muitíssimo nocivo, e dele nascem todas as coisas contrárias às boas; vício e dano. Se, pois, os homens nascem incapazes de viver cada um por si, se cedendo à necessidade vão ao encontro uns dos outros, e se toda a vida lhe propicia também os artefatos que a favorece, não é possível que eles estejam uns com os outros e levem a vida na ilegalidade (pois lhes seria um castigo maior acontecer isso do que aquele 
regime de cada um por si). Por causa dessas necessidades, com efeito, a lei e a justiça reinam entre os homens e de modo algum se as pode banir. Por natureza, pois, elas estão fortemente ligadas.

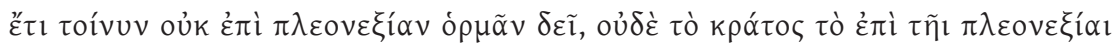

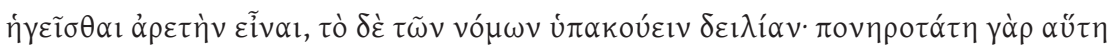

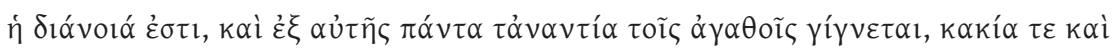

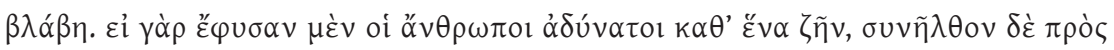

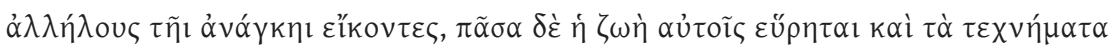

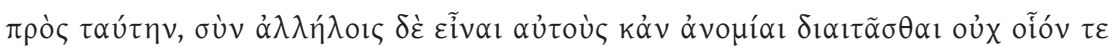

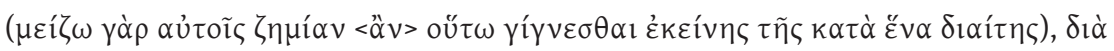

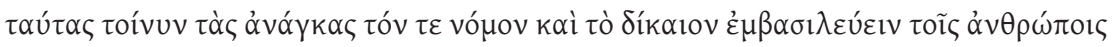

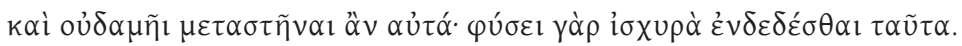

O poder monocrático, tirania ou monarquia, é claramente criticado no final do Anônimo de Jâmblico (DK 89, 7, 14), e determinado como derivação, por corrupção, do autêntico regime dos muitos:

Com efeito, sempre que estas duas, a lei e a justiça, abandonam o povo, logo a sua tutela e proteção partem para as mãos de um só; pois de que outra forma uma monarquia seria trazida para um só, senão tendo sido a lei alijada da conveniência da multidão?

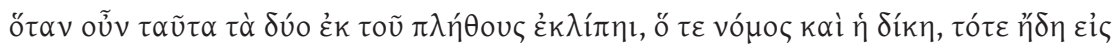

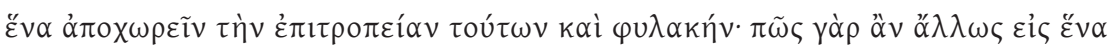

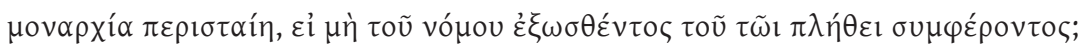

A tirania não vem de fora, como uma força primeira, a submeter a coletividade, mas vem do enfraquecimento da legalidade, subentende-se: do liame de consenso estabelecido pelos discursos, fiador da convivência pacífica da pluralidade. Platão tem razão, uma cidade democrática liga-se 
a indivíduos psicologicamente democráticos ${ }^{28}$, e a identidade do homem democrático se alimenta da contradição.

Poderíamos, como Platão, imaginar o homem democrático, que albergasse em sua alma a pluralidade característica da cidade democrática. Este aceitaria de antemão que, diante de toda assertiva a qual porventura viesse de alguma maneira chegar, haveria no reino dos discursos a assertiva contrária, e que, portanto, não estaria exilado da racionalidade aquele que lhe contradissesse. Antes o homem democrático, antilógico, buscaria explicitar todas as nuances que validam a assertiva contrária. E neste caso, "trazer no seu íntimo o inimigo e contraditor" 29 não teria nada a ver com o vício lógico da contradição, mas com a virtude política do pluralismo, com a legitimação a priori do direito do outro discurso.

É certo que a antilógica tem um lado negativo, pois o entrechocar-se dos discursos contrários leva ao sentimento de "nem um, nem outro", mas não é necessariamente cética (que suspende o juízo) nem niilista (que apenas nega), pois também tem um lado positivo que leva ao sentimento de "e um e outro". O asno de Buridan, se for cético, viverá de sua abstinência. Se for sofista, para não morrer de fome, comerá os dois montes de feno, sendo questão apenas de saber a oportunidade de comer um antes do outro e não na ordem inversa.

Voltando à macropolítica: também a civilização que quiser viver sob a égide da democracia terá de conviver com o risco do niilismo inerente à contradição. O cenário já é visível: toda questão, pequena ou grande - e abundam as pequeníssimas -, previamente cindida em dois campos de opinião, num binarismo repetitivo. Dois grandes partidos, um mais à direita, outro mais à esquerda, cada qual com seus quase 50\% do eleitorado, numa alternância tão pouco criativa e exangue quanto sói, pelo menos em tese, a democracia não ser. As curvas dos fenômenos humanos começam a se assemelhar às dos fenômenos climáticos, e justamente lá, onde o nomos deveria marcar sua diferença frente à natureza.

28 Cf. República 555b3-562a3.

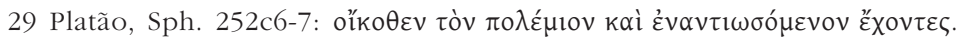


Que o binarismo engendre por si mesmo a reclamação por um terceiro, por um "três ou mais", ou seja, pelo plural propriamente dito, isso fica claro porque o "nem um nem outro" traz a questão de "qual então?", e este, excluído ou incluído, já é um terceiro. A própria visão do sábio antilógico não se confunde com nenhuma das duas que ele vê combater. O problema do discurso da terceira via é quando ele é tergiversação diante daquilo que exige uma leitura binária. E por várias modulações de humor a realidade pode aparecer decifrável pela chave dualista, dado um "é ou não é" básico, interpretável em vários sentidos. Mas há também outras modulações. E não lhes dar atenção seria reducionismo.

Interessante é ver a coerência entre a tese da antilogia (de que sobre tudo há dois discursos contrários um ao outro) com a ontologia da matéria supracitada. Sexto Empírico nos legou um testemunho sobre o sofista Protágoras (DK A14) que sugere por onde se possa fazer a articulação entre

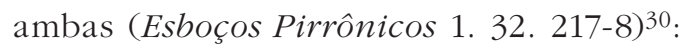

Protágoras diz que a matéria é alguma coisa que se esvai, e esvaindo-se de maneira ininterrupta, as adições vêm continuamente repor as perdas; quanto às sensações, elas variam e se transformam conforme as diferentes idades e os diferentes estados do corpo. Ele afirma em seguida que as razões de

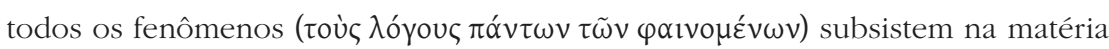
(ن்

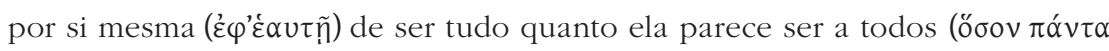

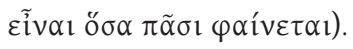

Num tal contexto, sobre cada coisa em causa, então, espera-se múltiplos discursos, até o limite dos dois discursos extremos, os reciprocamente contraditórios. Mas na sofística a antilogia não implica necessariamente equipolência, como no ceticismo. Fica de qualquer modo a pergunta: segundo qual medida de força se diz, em um par de enunciados contraditórios, que

30 Texto em Goold 1993. 
um é mais forte que o outro? E o que seria a capacidade de um discurso de mudar a relação de pesos nessa balança?

Talvez no domínio da matemática haja juízos sintéticos a priori, de tal modo que as negações desses juízos sejam necessariamente falsas. Talvez até no domínio de uma física - quem sabe? Mas certamente no da política, da ética, da estética, os juízos sintéticos estão fadados a escutar em revide o enunciado de sua solene negação. Certamente porque algo mudou no sujeito que percebe a coisa, ou porque algo mudou na coisa, ou porque é outro aspecto que o discurso quer enfatizar, de tal modo que é possível restaurar depois a univocidade pelo esclarecimento da perspectiva e pela manipulação asséptica da polissemia. Mas de qualquer forma os querelantes estão doravante numa rede do pró e do contra, a disputar no varejo qual dos dois discursos é a cada vez o adequado aos fatos. E, por mais que seja angustiante saber-se expulso do paraíso da univocidade, é em todo caso para se considerar um bem habitar um espaço em que o direito ao contraditório esteja garantido. A desvantagem e a vantagem correlatas da secularização inescapável.

Aristófanes satiriza bem a atmosfera de uma cidade assim secularizada (Eq. 1111-1130) $)^{31}$ :

Coro de cavaleiros: Ó, Demos, tens um belo governo; todos os homens te temem como a um bravo tirano. Mas és fácil de conduzir; agrada-te ser adulado e enganado, sempre bocejando diante daquele que fala e teu senso presente vai-se embora.

Demos: Vós é que não tendes um pingo de senso sob vossos cabelos ao pensar que não sou prudente: sou eu que voluntariamente me faço de ingênuo. Gosto de me embriagar o dia inteiro e alimentar um senhor ladrão: quando este estiver bem gordo, agarro-o e o dilacero.

\section{Xopós}

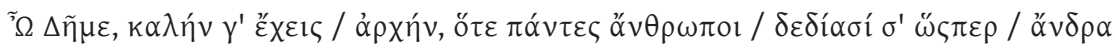

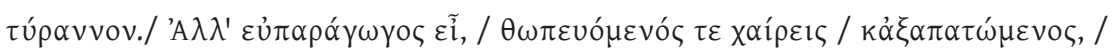

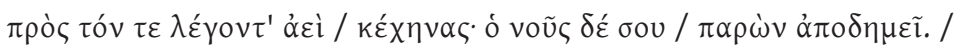


$\Delta \tilde{\eta} \mu \circ \varsigma$

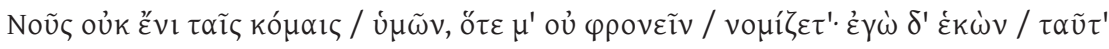

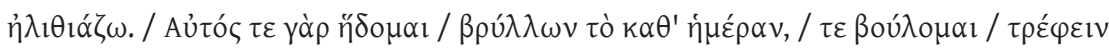

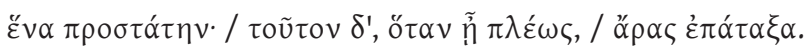

E testemunha quão a tagarelice acometeu até a tragédia, no rastro de Eurípides, o mais sofista dos tragediógrafos. Primeiro, pela fala de Héracles de descida ao Hades em As rãs (89-91):

Não há por aqui milhares de outros poetas jovens fazendo tragédias, incomparavelmente mais tagarelas que Eurípides?

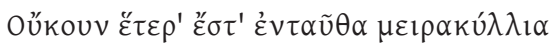

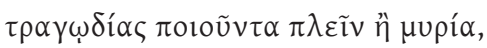

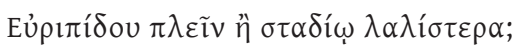

Depois pela fala de Éaco na mesma peça (772-9):

Quando Eurípides desceu aqui, exibiu-se aos ladrões de roupa, aos cortadores de bolsas, aos parricidas, aos furadores de muros, que eram então em grande número no Hades; os que ouviram suas antilogias, suas sutilezas e seus artifícios ficaram extasiados e o consideraram mais sábio, em seguida ele assumiu o trono em que Ésquilo se sentava.

'O

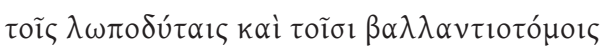

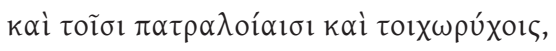

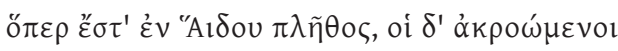

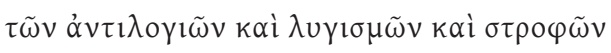

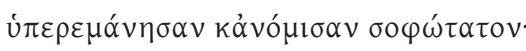

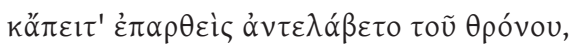

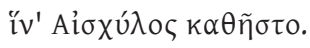


O cenário está completo: de um lado, oradores demagogos, que conduzem o demos tanto quanto são por ele conduzidos, de outro lado, o demos, louco como uma turba de bandidos, mas também sábio realista, que não rasga dinheiro, e sábio hedonista, a quem agrada estar a beber o dia inteiro. O hedonismo vem compor o ideário da finitude próprio da democracia, ao lado das outras noções já mencionadas: materialismo, agnosticismo, filodoxia, antilogia.

Não por acaso, Platão descreve a decadência do homem oligárquico no homem democrático concentrando-se na distinção, corrente na filosofia grega, entre prazeres necessários e prazeres não-necessários, afinal o homem oligárquico, ainda que já bem distante da suprema virtude, guarda alguma sobriedade e comedimento, em função de seu apego ao dinheiro. Quando, após lermos esse trecho do livro VIII da República, damos uma breve olhada para a profusão dos shopping centers, reais e virtuais, que infestam as metrópoles e outras poleis médias pretensamente democráticas e de livre-mercado, constatamos sem dificuldade que Platão está coberto de razão. Muito mais que Sócrates nas rústicas feiras de rua da antiguidade, teríamos motivos para exclamar no labirinto de vitrines climatizado artificialmente: "De quantas coisas não tenho necessidade!". 32 O problema aí de novo não é de razão estrito senso, a qual Platão costuma sempre ter, o problema é de monopólio ou socialização da razão - de nada vale ter razão sozinho ${ }^{33}$-, ou seja, o problema é de novo político. Quem é que vai determinar na cidade o que é necessário e o que não é? O consumo supérfluo é sempre o do outro, o meu consumo é do necessário, pode apostar. Então, não parece de bom alvitre atacar o hedonismo para ferir a decadente democracia. Separar o gozo do prazer pode ser eficaz para restituir disciplina na arena política e temperança na arena ética, mas, como o cobertor é curto, essa solução pode engendrar um tremendo problema psicanalítico nos imaginários individuais e coletivos. O sofista Antifonte já fundara na antiguidade uma espécie de consultório psicanalítico

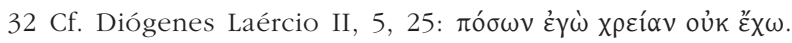

33 Cf. Castoriadis 1986: 302, quando o autor destaca a súplica de Hemon a Creonte no verso 707 da Antígona de Sófocles, para que o regente tebano não queira "ser sábio sozinho" ("être sage tout seul [monos phronein]"). 
a pretexto de uma "arte da não-dor" (techne alypias) ${ }^{34}$. Bastava essa negativa da dor, nem era preciso uma formulação positiva do prazer.

Quem vai determinar na cidade o que é necessário e o que não é? E qual será em última instância o critério a legitimar a ordem que toda cidade deve ser? O "povo" parece ser a essa altura da história a melhor resposta. Talvez a riqueza desse critério esteja exatamente em seu defeito, sua vagueza e indeterminação. E quem decide se o nome "povo" está sendo bem interpretado ou se está sendo espuriamente apropriado por um interesse particular? E quando for o caso de o povo precisar destituir a ordem que o próprio povo instituiu? Recentemente o filósofo brasileiro Vladimir Safatle declarou em entrevista algo nesse sentido ${ }^{35}$ :

Se todo poder emana do povo, o povo é o poder soberano. O povo está dentro da lei e fora da lei. Está dentro da lei porque é o fundamento da lei. Está fora porque pode destituir a lei quando bem lhe aprouver, porque o povo é o legislador de si mesmo. A tendência da democracia é saber integrar o poder destituinte do povo.

Tudo lindo, como a república de Platão, o problema é quem decide em cada caso se o povo está de fato sendo legislador de si mesmo ou se é qualquer outra artimanha que está em jogo, ficando apenas o nome. Quem decide quando se trata de legítimo poder destituinte do povo, ou de ilegítima destituição de seu legítimo poder constituinte? Esse imbróglio já era conhecido dos gregos e fazia parte do debate de Platão com os sofistas. Aparentemente trata-se de certo desdém irônico do primeiro relativamente aos segundos toda aquela história de que, enquanto uma lei vigora, ela é boa e verdadeira, mas, uma vez revogada, deixa de sê-lo. Como assim, a bondade e a verdade à mercê da convenção efêmera e mutável? Não seria a revogação posterior prova de que a convenção anterior estava errada? Mas a ironia de Platão pode ser lida também, a despeito de qualquer que seja sua intenção

34 DK 87 A6, Pseudo-Plutarco, Vidas dos dez oradores 833c-d [18].

35 Entrevista ao blog Diário do Centro do Mundo na TVT, maio de 2016. 
consciente, como sintoma, como mise-en-scène de uma filosofia da finitude que é a mesma inferida da posição de certa sofística.

Por essa filosofia, não seria o caso de dizer que a verdade, a bondade ou a justiça não existam, ou que a lei convencionada nada tenha a ver com elas, mas sim que a lei sempre seja convencionada com os olhos a tentar ver o melhor, o mais justo e o mais verdadeiro no contexto conflituoso de muitas verdades e concepções de bem e justiça, apenas que o que aparece para esses olhos haverá de ficar sempre aquém de um êxito exaustivo que dirimisse o conflito, e que haverá fatalmente de mudar, o que forçará, portanto, a mudar também a lei que o tenta mimetizar. E provavelmente essa formulação não seria rejeitada nem por Platão, exímio descritor da finitude humana ${ }^{36}$, nem pelos sofistas, de quem vêm as formulações mais explícitas dessa finitude. Como esta de Antifonte ${ }^{37}$ :

Espantosamente, ó bem afortunado, é fácil acusar toda a vida, pois não tem nada que extrapole o limite, nada de grandioso, nem de solene, mas todas as coisas são pequenas, frágeis, breves e misturadas com grandes dores.

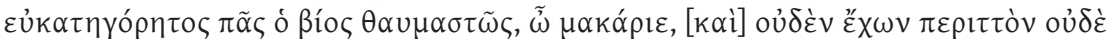

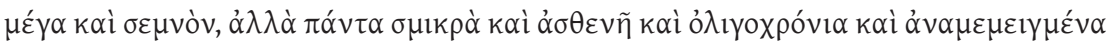
$\lambda u ́ \pi \alpha \iota \varsigma \mu \varepsilon \gamma \alpha \dot{\lambda} \alpha \iota \varsigma$.

Quem diz o que é ou não? A questão do poder, a questão do "quem", é também questão de ontologia, por causa do "é ou não". Mas ainda questão de dizer. De comunicação social, dir-se-ia hodiernamente. De retórica, dir-se-ia à moda antiga. E a história recente do Brasil está aí para mostrar como um governo democraticamente eleito, voltado um pouco mais que de costume para as massas desfavorecidas, mas negligente quanto à questão

36 Cf. República VI 486a (tradução em Rocha Pereira 1983): "Mas aquele que possuir um espírito superior e contemplar a totalidade do tempo e a totalidade do ser, supões que é

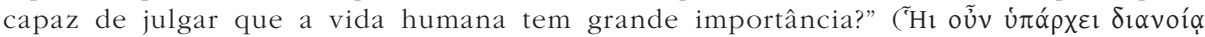

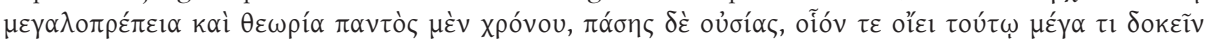

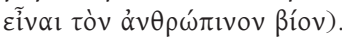

37 DK 87 B51, Estobeu, Anthologium 4. 34.56. 
da comunicação, pode cair, num peteleco jurídico-midiático da elite, sem que haja resistência popular. É por isso que se precisa de sofistas em uma democracia. O microfone não pode ficar sempre nas mãos dos mesmos. Discurso único embota um povo inteiro.

\section{Bibliografia Citada}

Agamben, G. et al. (2009), Démocratie dans quel état?. Montréal.

Burnet, J. (1907/1987), Platonis Opera. Oxford.

Castoriadis, C. (1986), "La polis grecque et la création de la démocratie", in Domaines de l’homme. Les carrefours de labyrinthe II. Paris.

Diels, H. \& Kranz, W. (1952), Die Fragmente der Vorsokratiker, 6a ed. Zürich. [DK]

Gall, F. W. \& Geldart, W. M. (1907), Aristophanis comoediae. Oxford.

Goold, G. P. (1925/1991), Diogenes Laertius: Lives of Eminent Philosophers. Cambridge-London.

Goold, G. P. (1933/1993). Sextus Empiricus: Outlines of Pyrrbonism. Cambridge-London.

Goold, G. P. (1935/1983). Sextus Empiricus: Against the Logicians. Cambridge-London.

Jaeger, W. (1957/1985), Metaphysica. Oxford.

Mathieu, G. (1942), Isocrate: Discours, Tome III. Paris.

Monro, D. B. \& Allen, T. W. (1902/1991), Homeri Ilias. Oxford.

Nietzsche, F. (1873), Über Wahrheit und Lüge im außermoralischen Sinne. Leipzig.

Rocha Pereira, M. H. (1983), Platão: A república. Lisboa.

Rabe, H. (1896), Commentaria in Aristotelem Graeca. Berlin.

Solmsen, F. (1970/1990), Hesiodi Theogonia Opera et Dies Scutum. Oxford.

Stuart Jones, H. (1942) Thucydidis Historiae. Oxford.

Santos, J. G. T. (2002), Parmênides: Da Natureza. São Paulo. 